\title{
Tissue quantification of neutral and acid mucins in the mucosa of the colon with and without fecal stream in rats ${ }^{1}$
}

\author{
Quantificação tecidual de mucinas neutras e ácidas na mucosa do cólon com e sem trânsito \\ intestinal em ratos
}

\author{
Ronaldo Nonose ${ }^{\mathrm{I}}$, Ana Paula Pimentel Spadari ${ }^{\mathrm{II}}$, Denise Gonçalves Priolli ${ }^{\mathrm{III}}$, Felipe Rodrigues Máximo ${ }^{\mathrm{II}}$, José Aires Pereira ${ }^{\mathrm{IV}}$, \\ Carlos Augusto Real Martinez ${ }^{\mathrm{V}}$ \\ ${ }^{I}$ Fellow Master Degree, Post-graduate Program in Health Sciences, USF, Bragança Paulista - SP, Brazil.

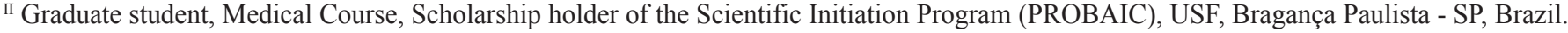 \\ III Associate Professor, Post-graduate Program in Health Sciences, USF, Bragança Paulista - SP, Brazil. \\ Iv Assistant Professor, Division of Pathology, USF, Bragança Paulista - SP, Brazil. \\ ${ }^{v}$ Associate Professor, Post-graduate Program in Health Sciences, USF. Surgeon-in-Chief of Sao Francisco University Hospital (HUSF), Brazil.
}

\begin{abstract}
Purpose: To quantify the intensity of the expression of neutral and acids mucins in mucosa of the colon with and without fecal stream and to correlate this with the duration of fecal transit diversion. Methods: Thirty male Wistar rats were subjected to fecal transit deviation in the left colon by a proximal colostomy and a distal mucous fistula. The animals were divided into three experimental groups, according to whether sacrificing would be performed six, 12 or 18 weeks after surgery. The expression of neutral and acid mucins was evaluated using the histochemical techniques of Periodic Acid Schiff and Alcian Blue, respectively. The tissue mucins expression was quantified by computer-assisted image analysis software (NIS-Elements) in the segments with and without fecal stream. Student's paired $t$ test was used to compare the quantities of mucins in colon with or without fecal stream and variance between the experimental groups by ANOVA and Newman-Keuls post-test, establishing level of signification of $5 \%(p<0.05)$. Results: There were significant decreased quantities of acid and neutral mucins in the colon without transit, compared with the colon with fecal stream, independent of the duration of exclusion. There was increased expression of neutral mucins in the colon with fecal stream after 12 and 18 weeks of exclusion. There was no increase in the expression of acid mucins in the colon with transit as the duration of fecal transit exclusion progressed. There was increased production of acid mucins in the animals submitted to diversion of the fecal stream for 18 weeks, compared with those subjected to diversion for 6 and 12 weeks. In the colon without fecal stream, there was increased expression of neutral mucins after 12 and 18 weeks of exclusion. Conclusions: Deviation of the fecal stream decreased the expression of acid and neutral mucins in the segments without fecal transit, compared with segments with transit. Regardless of the reduced expression of acid and neutral mucins in the segments without fecal stream, their tissue expression increased with increasing duration of intestinal deviation.
\end{abstract}

Key words: Colitis. Colostomy. Mucins. Sialomucins. Image Processing, Computer-Assisted.

\section{RESUMO}

Objetivo: Quantificar a intensidade de expressão de mucinas neutras e ácidas na mucosa cólica provida e desprovida de trânsito intestinal relacionando-a ao tempo de exclusão fecal. Métodos: Trinta ratos Wistar machos foram submetidos à derivação do trânsito no cólon esquerdo por colostomia proximal e fístula mucosa distal. Os animais foram divididos em três grupos experimentais segundo o sacrifício ter sido realizado seis, 12 e 18 semanas após a cirurgia. A avaliação da expressão de mucinas neutras e ácidas na mucosa cólica foi realizada com as técnicas histoquímicas do Periódico Ácido de Schiff e Azul de Alcian, respectivamente. A quantificação da expressão tecidual das mucinas foi com auxílio de programa de análise de imagem assistida por computador (NIS-Elements) nos segmentos providos e desprovidos de trânsito fecal. Utilizou-se o teste t de Student pareado na comparação da expressão de mucinas nos segmentos com e sem trânsito e a variação na expressão entre os grupos experimentais pelo teste ANOVA e pós-teste de Newmann-Keuls, estabelecendo-se nível de significância de 5\% (p<0,05). Resultados: Houve redução na quantidade de mucinas neutras e ácidas no cólon desprovido de trânsito quando comparado ao cólon provido de trânsito, independente do tempo de exclusão. Ocorreu aumento na expressão de mucinas neutras no cólon provido de trânsito intestinal após 12 e 18 semanas de exclusão. Não houve aumento na expressão de mucinas ácidas no cólon provido de trânsito com o progredir do tempo exclusão de trânsito fecal. Ocorreu aumento na produção de mucinas ácidas nos segmentos com exclusão de trânsito por 18 semanas quando comparados aos animais submetidos à exclusão por seis e 12 semanas. No cólon desprovido de trânsito ocorreu aumento na expressão de mucinas neutras após 12 e 18 semanas de exclusão. Conclusões: A derivação do trânsito fecal diminui a expressão de mucinas ácidas e neutras nos segmentos desprovidos de trânsito fecal quando comparado aos segmentos providos de trânsito. Não obstante a redução da expressão de mucinas neutras e ácidas nos segmentos desprovidos de trânsito fecal existe aumento na sua expressão tecidual com o progredir do tempo de derivação intestinal.

Descritores: Colite. Colostomia. Mucinas. Sialomucinas. Processamento de Imagem Assistida por Computador.

${ }^{1}$ Research performed at Post-graduate Program in Health Sciences, Sao Francisco University (USF), Bragança Paulista - SP, Brazil. 


\section{Introduction}

In 1981, Glotzer et al. ${ }^{1}$ were the first to describe the development of an inflammatory process in the mucosa of colon segments without fecal stream. They called this new form of inflammatory bowel disease (IBD) diversion colitis (DC). Subsequently, it has been demonstrated that the etiopathogenesis of DC is related to intraluminal deficiency of short-chain fatty acids (SCFA), which are the main energy substrate for the cells of the colon epithelium.

DC presents clinical, macroscopic and microscopic characteristics that resemble ulcerative colitis (UC). Clinically, patients with DC present elimination of variable quantities of mucus and blood from the segment without fecal stream. The disease is diagnosed by histopathological examination of fragments of colon mucosa that are obtained while performing endoscopic examinations. As seen via endoscopy, excluded segments of colon mucosa may vary in appearance from macroscopically normal to differing degrees of inflammation, with erythema, friability, erosion with spontaneous bleeding, edema or inflammatory polyps ${ }^{2}$. In more severe cases, aphthoid ulcers that are practically indistinguishable from those found in cases of UC are formed ${ }^{3}$. These characteristics, especially in patients undergoing intestinal deviation because of complications from $\mathrm{UC}$, make it problematic to determine the differential diagnosis between exacerbation crises of the preexisting disease and the development of DC. Consequently, this makes it difficult to indicate that the intestinal transit should be reestablished ${ }^{4}$.

The results from histological studies on patients with DC have been controversial. This shows that the course of the disease presents a variety of pathological changes and thus there is no characteristic pattern ${ }^{4,5,6}$. The most common changes include erosion or ulceration of the mucosa, nonspecific chronic inflammatory processes, diffuse nodular lymphoid hyperplasia, cryptitis, inflammatory infiltrate in the lamina propria, atrophy of the muscle layer and characteristically mucins depletion in the colon epithelium ${ }^{4,6}$.

The histochemical expression of mucins in the colon mucosa is well known and, selectively, the presence of neutral and acid mucins can be demonstrated ${ }^{7}$. The acid mucins, in turn, are composed of sulfomucins and sialomucins ${ }^{7}$. The proportions between neutral and acid mucins are constant and may be modified in IBD and changes to the tissue expression of this glycoprotein in the colon mucosa of patients with UC have already been demonstrated ${ }^{7,8}$. It has also been shown that such changes may even precede the development of neoplasia ${ }^{7,8}$. Likewise, changes to mucin synthesis and distribution along the mucosa of colon segments without fecal stream that are used as reservoirs or by-pass for reconstituting the urinary transit have been demonstrated $^{9,10,11}$. This suggests that alterations to the expression of these glycoprotein might, in these patients, be considered to be precursory changes for neoplasm development ${ }^{9,10}$.

Despite the histopathological similarities between UC and DC, to the best of our knowledge, only a single experimental study has evaluated, specifically, the quantification and modifications to acid mucins expression in experimental model of $\mathrm{DC}^{5}$. In that study, changes to the locations and expression intensity of acid mucins were found, and these were correlated with the duration of fecal transit exclusion ${ }^{5}$. However, the neutral mucins was not evaluated and the quantification of the acids mucins was conducted subjectively and its concentration in the colon epithelium was not quantified using methodology of greater precision. With the advent of computer-assisted image analysis software, it has become possible to precisely determine macroscopic and microscopic changes such as number of goblet cells and the tissue expression of various substances ${ }^{11,12,13}$. With this technology, the neutral and acids mucins expression in the colon mucosa can be quantified, and the possibility of differences in total content between segments with and without fecal stream can be investigated, along with the influence of the duration of intestinal exclusion on the intensity of expression of these glycoprotein's.

The aim of the present study was to quantify the tissue expression of neutral and acid mucins in the colon mucosa, in colon segments with and without intestinal transit, by means of computerized morphometry, and to investigate the influence of the duration of fecal exclusion.

\section{Methods}

This study was conducted in accordance with Federal Law No. 6,638 and the guidelines of the Brazilian College for Animal Experimentation (COBEA). It received approval from the Research Ethics Committee of São Francisco University, Bragança Paulista, Sao Paulo, Brazil.

Thirty male rats Wistar (Rattus norvegicus albinus), from the Multidisciplinary Center for Biological Investigation of the Campinas State University (CEMIB-UNICAMP) were used. They weighed between 300 and 380 grams and had a mean age of four months. They were distributed randomly into three experimental groups of 10 animals, according to the length of time for which they would be kept after surgery, until sacrificing: 6 weeks (group A), 12 weeks (group B) or 18 weeks (group C).

On the day before the surgical procedure, the animals were kept in individual cages, under fasting conditions (except for water), for 24 hours. After being individually identified, they were weighed and anesthetized using $2 \%$ xylazine hydrochloride plus ketamine hydrochloride, at a dosage of $0.1 \mathrm{ml} / 100 \mathrm{~g}$, administered intramuscularly. The abdominal cavity was accessed by a median longitudinal incision of three centimeters in length, and the left colon was identified. With the aid of a pachymeter and after ligature of the vessels of the marginal arcade, the left colon was sectioned four centimeters above the proximal extremity of Peyer's patch. After removing any fecal content that might have been present, the proximal segment of the left colon was brought to the exterior as an end colostomy, attached to the skin. The distal segment of the sectioned colon was catheterized using a $12 \mathrm{~F}$ polyvinyl probe and was irrigated with $0.9 \%$ physiological solution until the effluent draining out through the animal's anus no longer included any fecal material. After this irrigation, the catheter was removed and the distal colon was brought to the exterior as a distal mucous fistula on the lower left lateral face of the abdominal wall. The abdominal wall was closed as two sutured layers (peritoneum and aponeurosis). After concluding the operation, the animals were housed in individual cages and were allowed to have water and standard feed, once they had recovered movements. They remained in a climate-controlled environment, with temperature and lighting regulation, and they were weighted every week. No additional care was provided with regard to the operative wound and the stoma that had been constructed. 
For sacrificing, the animals were kept fasting for 24 hours, except for water. They were again anesthetized, using the same technique as described earlier, and underwent median laparotomy to remove all the colon segments with and without fecal transit. To ensure uniformity in the histological analysis, the specimens (measuring three centimeters in length) were always collected from a predetermined location, one centimeter from the internal attachment of the stoma on the parietal peritoneum. The resected colon segments with transit from each animal were taken as the control group for the alterations to the colon without transit, in order to avoid the influence of weight gain on any histological changes that might be found. The euthanasia was carried out by lethal dose of anesthetic drug.

The resected segments were opened up longitudinally, along the anti-mesocolic margin, and were laid out and attached to a piece of cork, with the mucous surface upwards. The specimens were fixed by immersing in a $10 \%$ buffered formaldehyde solution for 72 hours. They were then dehydrated in successively increasing concentrations of alcohol and clarified in xylene. The material was embedded in paraffin blocks and four longitudinal sections of $4 \mu \mathrm{m}$ in thickness were cut, perpendicular to the mucous surface, for histopathological and morphometric analysis.

All the slides were stained using the hematoxylin-eosin technique in order to evaluate the histological changes found. The tissue expression of the neutral mucins was determined individually by means of the modified histochemical technique of Periodic Acid Schiff (PAS) ${ }^{14}$, while the expression of acid mucins was determined using the Alcian Blue $(\mathrm{AB})$ technique. The slides were read under an ordinary optical microscope with a final magnification of 200x. The histological parameters were analyzed qualitatively and quantitatively by a pathologist with experience of diseases of the digestive tract who was unaware of the origin of the material and the objectives of the study.
The neutral mucins stained magenta, while the acid mucins stained blue. The expression of neutral and acid mucins was quantified by means of computer-assisted image processing and was always performed in a focal field in which there were at least four complete and contiguous colonic crypts, with a magnification of $200 x$. The images selected were captured on a video camera that had been coupled to an optical microscope. These images were processes and analyzed using the NIS-Elements software, installed in a microcomputer with good image processing capacity. By means of colored histograms in RGB system the software determined the color intensity in number of pixels in each field selected, and transformed the final data into percentage expressions by analyzed fields. The final value taken for each field measured in the segments with and without intestinal transit was the mean of the values found from evaluating three different fields.

The statistical analysis on the results obtained was performed by taking the significance level of $5 \%(\mathrm{p} \leq 0.05)$. The data from each colon segment analyzed, in each experimental group, were expressed as the mean value with the respective standard error, and were analyzed using the SPSS for Windows statistical software (version 13.0). To compare the mucin content in the segments with and without transit, Student's t paired test was used. To analyze the variance in the mucin expression between the different experimental groups, ANOVA was used with the Newman-Keuls post-test.

\section{Results}

Figure 1 shows the expression of neutral mucins, evaluated using the PAS technique in segments with and without intestinal transit, in animals subjected to six weeks of fecal transit exclusion.

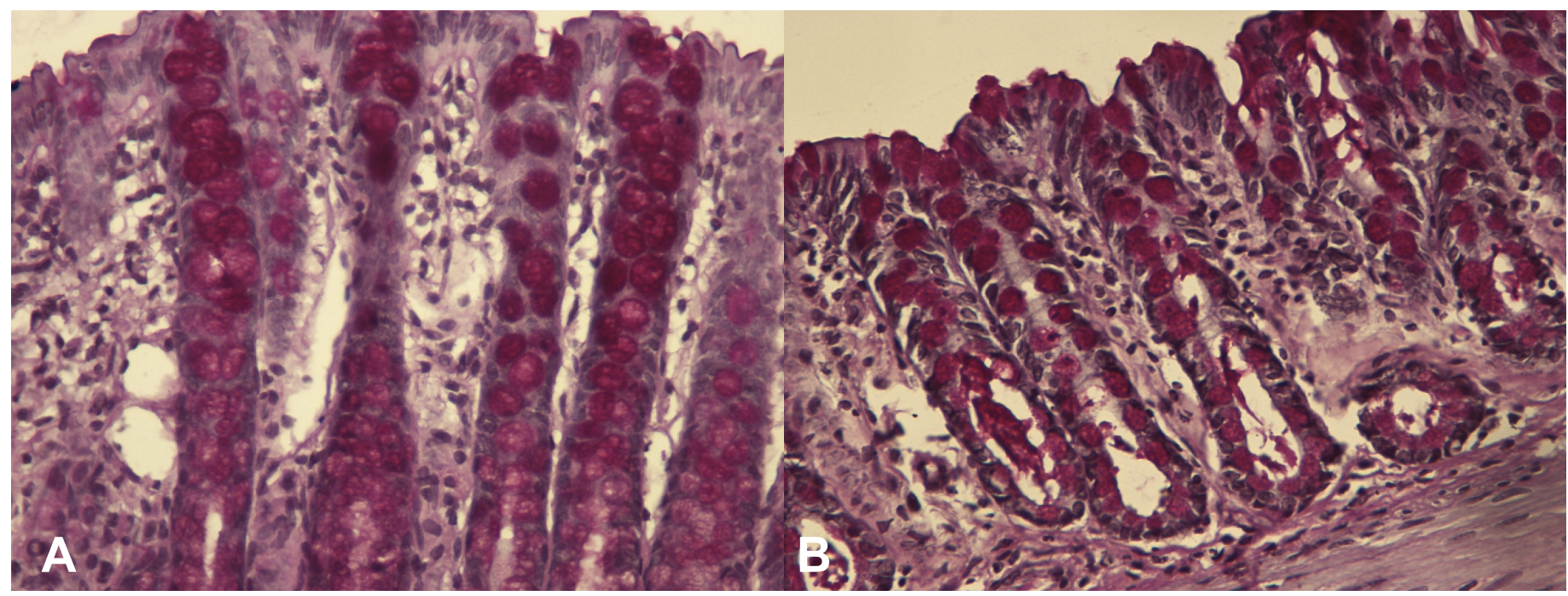

FIGURE 1 - Animals subjected to fecal transit exclusion for six weeks (group A). A - Expression of neutral mucins in the colonic glands in a segment with fecal transit (PAS 200x). B - Expression of neutral mucins in the colonic glands in a segment without fecal transit (PAS- 200x) 
Figure 2 shows the mean with respective standard errors from quantification of neutral mucins comparing colon segments with and without intestinal transit, for different durations of exclusion. Significant reductions in the quantities of neutral mucins were found in the segments without fecal stream in relation to those with fecal stream independent of the duration of the exclusion time.

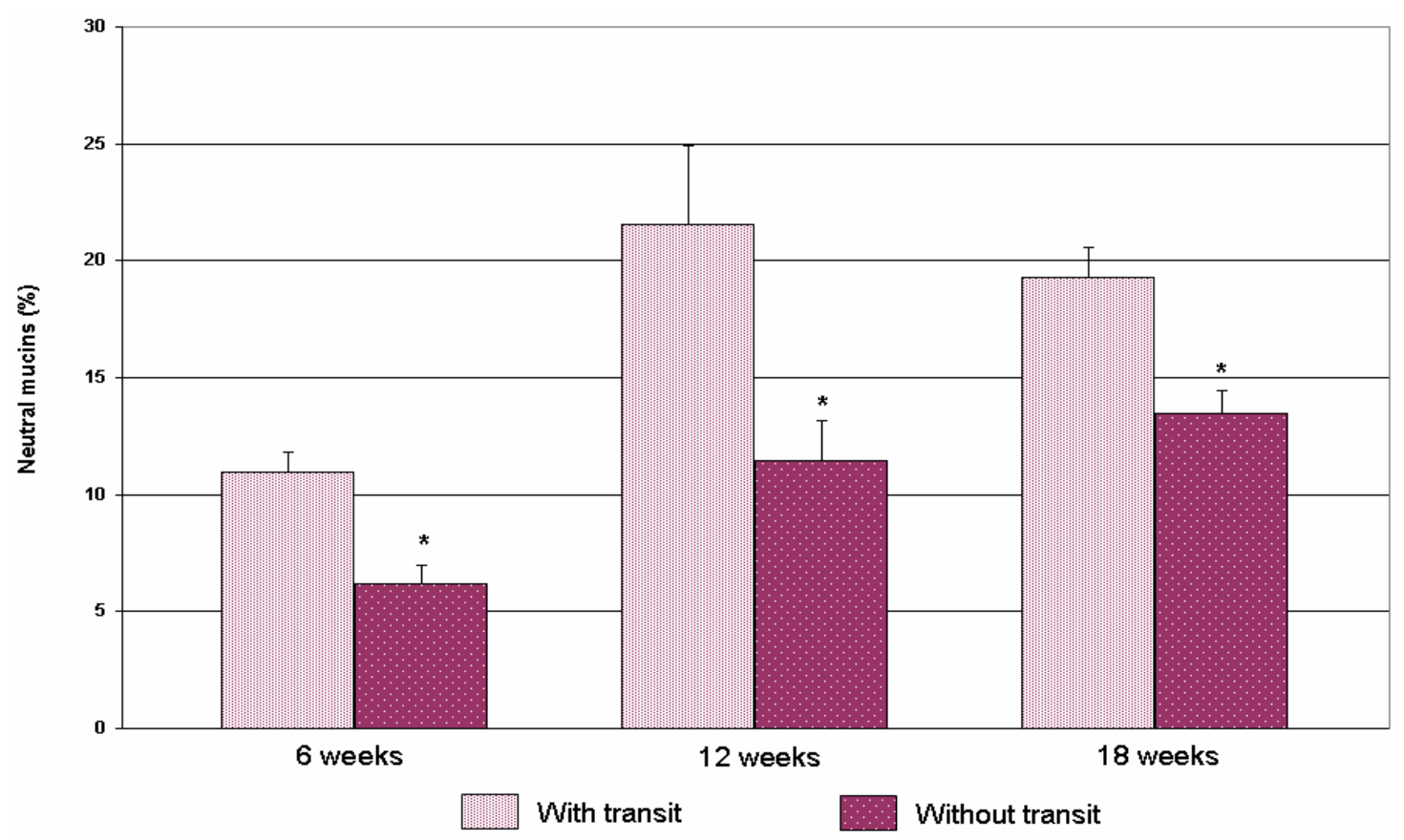

FIGURE 2 - Comparison between the percentage expression of neutral mucins in segments with and without fecal transit for different durations of exclusion. * = significant; Student's t test

Figure 3 shows the expression of acid mucins in segments with and without intestinal transit, evaluated using the
$\mathrm{AB}$ technique, in animals subjected to 12 weeks of fecal transit exclusion.

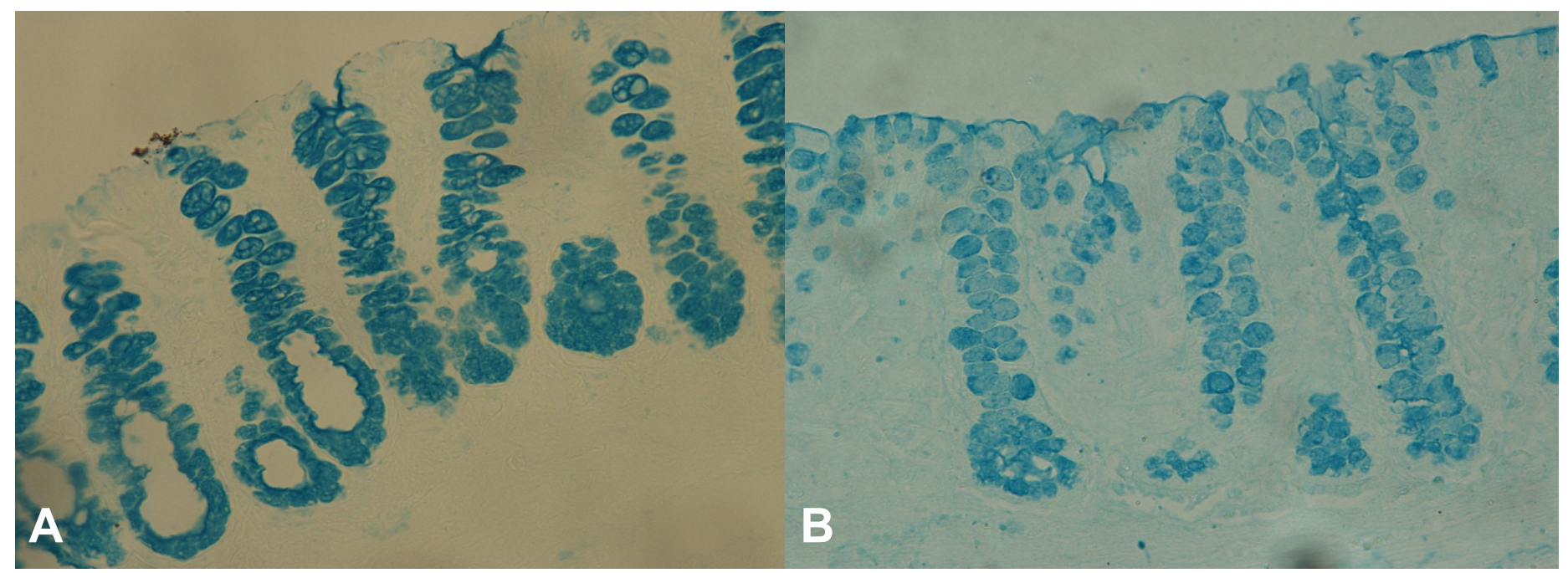

FIGURE 3 - Animals subjected to intestinal transit exclusion for 12 weeks (group B). A-Expression of acid mucins in colonic glands in a segment with fecal transit (AB -100x). B - Expression of acid mucins in colonic glands in a segment without fecal transit (AB 100x) 
Figure 4 shows the mean with respective standard errors from quantification of acid mucins in colon segments with and without fecal transit for different durations of exclusion.
Significant reductions in the quantities of acid mucins were found in the segments without fecal stream in relation to those with transit fecal stream independent of the duration of exclusion considered.

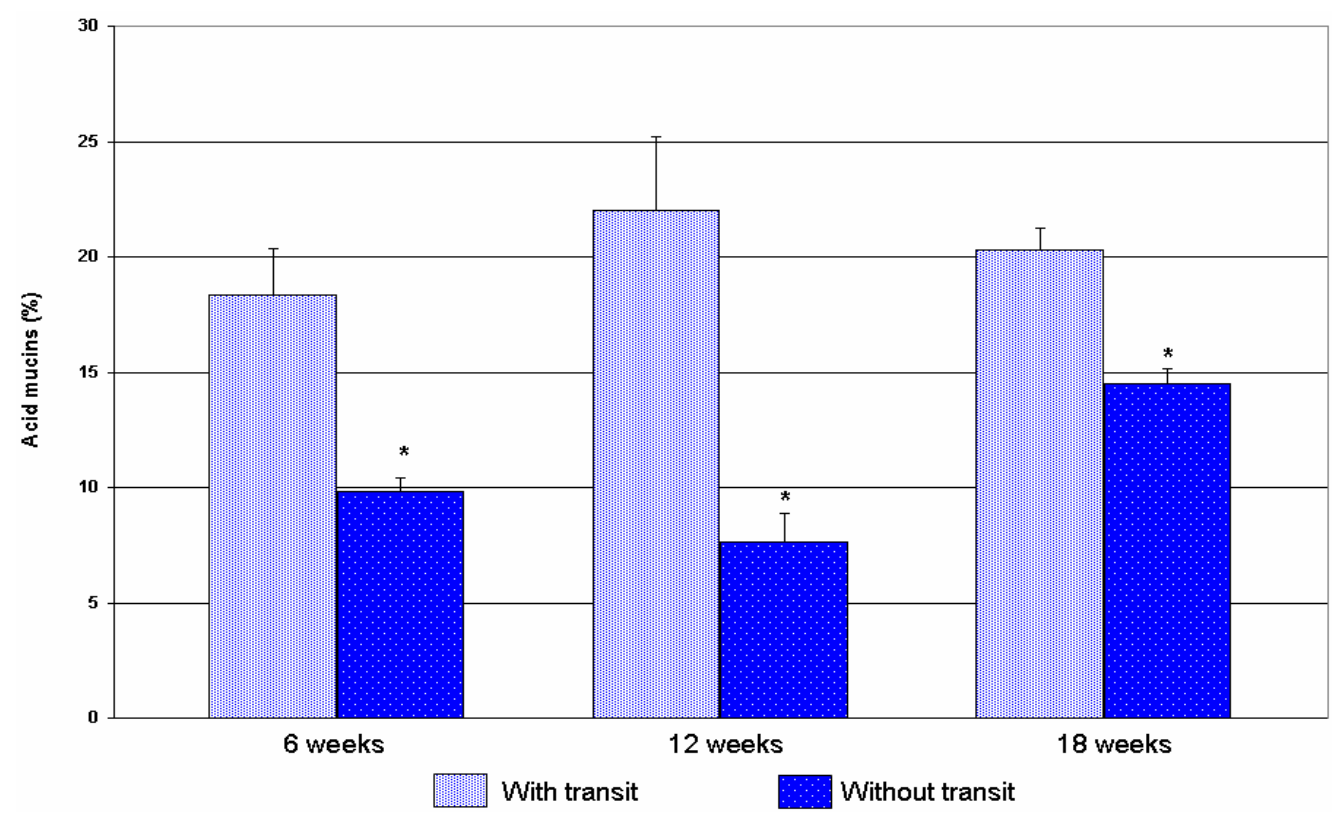

FIGURE 4 - Comparison between percentage expressions of acid mucins in segments with and without fecal transit for different durations of exclusion. * = significant; Student's t test

Figure 5 shows the mean with respective standard errors from quantification of neutral and acid mucins in colon segments with fecal stream for different durations of exclusion. In the colon with transit, the quantity of neutral mucins increased between the exclusion durations of six and 12 weeks and stabilized from 12 weeks onwards. The quantity of acid mucins does not increase with the time of exclusion.

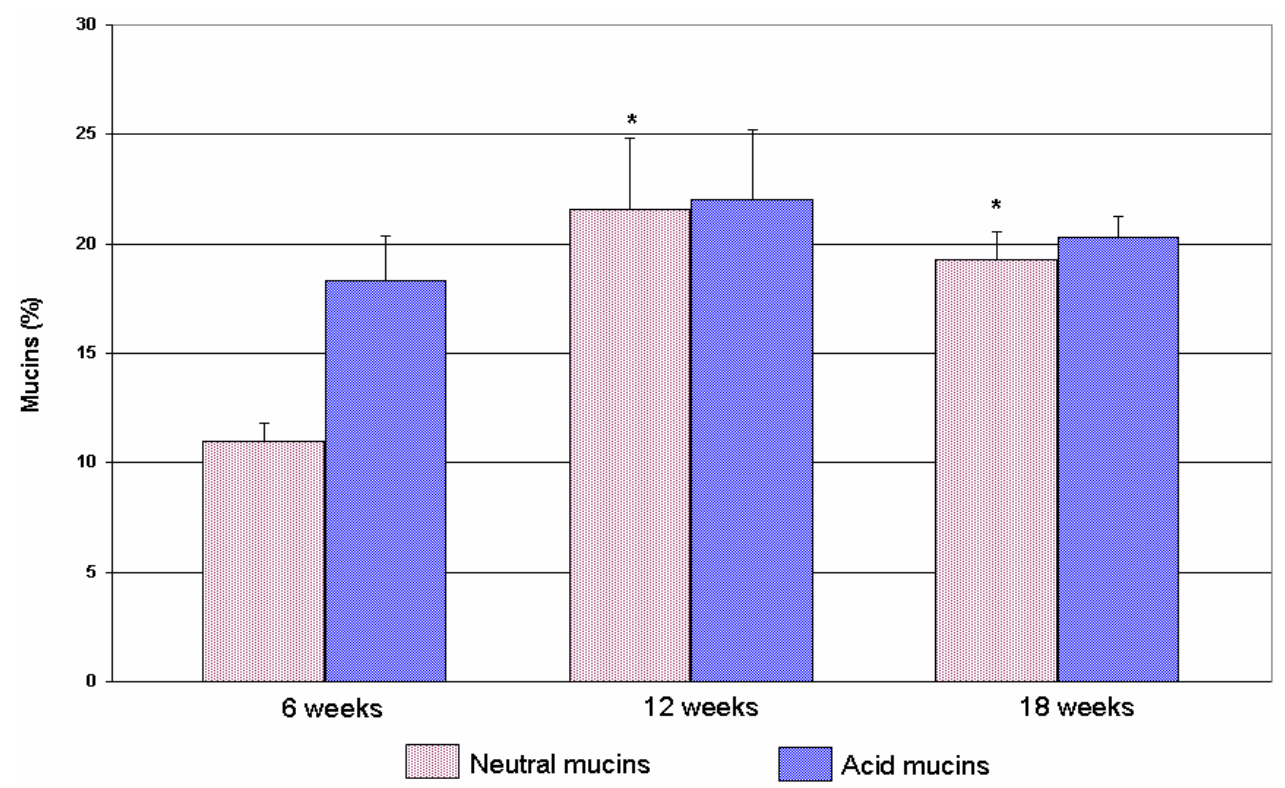

FIGURE 5 - Variation in the percentage expression of neutral and acid mucins in segments with fecal transit for different durations of exclusion. ${ }^{*}=$ significant; ANOVA - Newman-Keuls: neutral mucins (group B versus A and group C versus A) 
Figure 6 shows the mean with respective standard errors from quantification of neutral and acid mucins in colon segments without fecal stream for different durations of exclusion. The tissue quantities of neutral mucins in the segments excluded from fecal stream increase with the time of exclusion. The quantities of acid mucins in colon segments without fecal stream increase significantly only after 18 weeks of fecal exclusion.

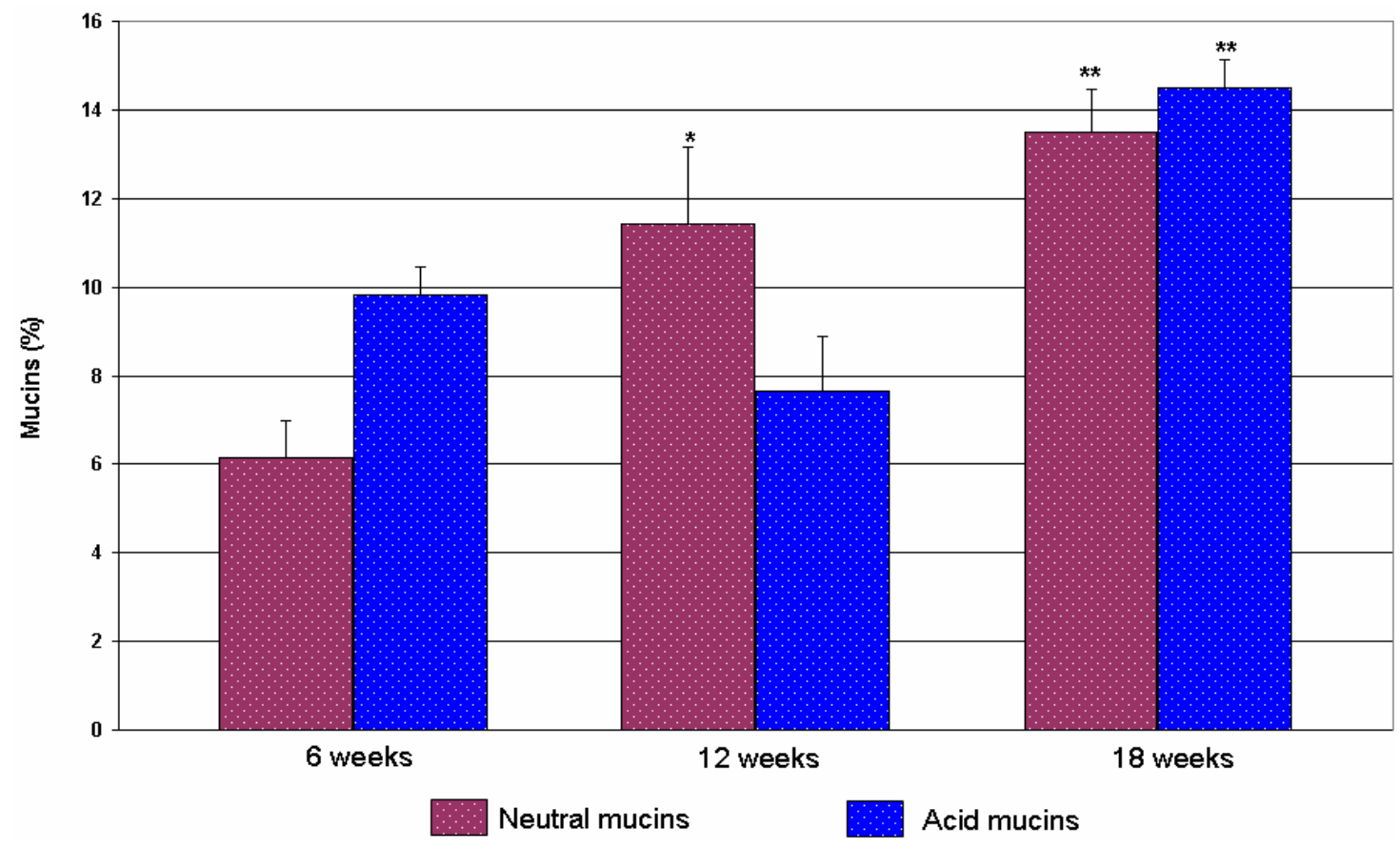

FIGURE 6 - Variation in the percentage expression of neutral and acid mucins in segments without fecal transit for different durations of exclusion. * = significant; ANOVA - Newman-Keuls: neutral mucins (group B versus A; group $\mathrm{C}$ versus $\mathrm{A}$ and $\mathrm{B}$ ); acid mucins (group C versus A and B)

\section{Discussion}

The main function of the mucus in the lumen of the colon is to serve as protection for the epithelial cells of the intestinal mucosa ${ }^{15}$. The mucus forms a gelatinous barrier that adheres to the epithelial cells, thus making translocation of bacteria into the colon wall difficult ${ }^{15}$. Most of the protective effect of the mucus relates to the presence of mucins, which are the predominant glycoproteins in the composition of the colonic mucus ${ }^{15}$. Through the use of histochemical ${ }^{16}$ and biochemical ${ }^{17}$ techniques, abnormalities in mucus production and expression have been shown in the IBD that affect the large intestine. The mechanism responsible for these abnormalities is still a subject for research ${ }^{17}$. Recently, it was demonstrated that the reactive oxygen species that are present in the intestinal lumen or are produced through energy metabolism of the epithelial cells of the colon mucosa fragment the mucin molecules covering the epithelium and cause lesions to the intercellular junctions and basal membrane ${ }^{18}$. This allows invasion of the sterile submucosa by intraluminal bacteria and antigens, thus triggering the inflammatory reaction seen in cases of $\mathrm{UC}^{18,19}$. It has also been demonstrated that the changes in energy supply to colonocytes that are seen in DC patients form reactive oxygen species, and this is related to the emergence of $\mathrm{DC}^{20}$. Like in cases of UC, modifications to mucus secretion are one of the most important elements in the histological spectrum of DC and when demonstrated, this is a useful parameter for diagnosing the disease ${ }^{5}$.
The expression of mucins in the colon epithelium is well known and can be categorized by histochemical techniques as neutral or acid ${ }^{9}$. According to their content of sialic acid or sulfate, the acid mucins are, in turn, subdivided into sialomucins and sulfomucins ${ }^{9,21}$. Neutral mucins are usually evaluated using the PAS technique, although the conventional technique may give rise to concomitant staining of small quantities of sialomucins. With the aim of only staining the neutral mucins, the methodology proposed by Gilks et al. ${ }^{14}$ was adopted in the present study, to eliminate the cross-positivity with acid mucins. However, differing from those authors, separate staining of acid mucins using the AB technique was performed in the present study.

The colon with fecal stream in those animals that underwent colon diversion for 12 and 18 weeks had 50\% and 44\% more mucins, respectively, than was seen in the animals with deviation for six weeks. It is possible that these higher values in segments with fecal stream were related to the increased thickness of the colonic crypts consequent to the weight increases that the animals presented with the passage of the weeks and the trophy effect of SCFA on the colon epithelium. In the colon with fecal stream, the quantity of mucins increased between the exclusion durations of six and 12 weeks and stabilized from 12 weeks onwards. Significant reductions in the total quantities of neutral mucins were found in the segments without fecal stream, in the present study, in relation to those with transit, of $43 \%, 46 \%$ and $30 \%$ after 6,12 and 18 weeks, respectively. It is possible that the 
reduction in the expression of neutral mucins in the segments without fecal stream may be related to several factors, of which the following can be highlighted: absence of intraluminar contents of SCFA, reduced thickness of the colonic crypts, reduced of cell proliferation of the colonic crypts, modifications to the bacterial flora and alterations in mucins synthesis. These results are concordant with findings described previously, and they demonstrate that the presence of SCFA stimulates mucins synthesis through exerting a trophic effect on the colon epithelium, thus increasing cell proliferation ${ }^{15}$. The smaller population of bacteria resulting from mechanical cleaning of the colon without transit may also be related to the lower mucin expression in the excluded segment, as demonstrated earlier ${ }^{22}$.

The tissue quantities of neutral mucins in the segments excluded from fecal transit were significantly greater in the animals subjected to exclusion for 12 and 18 weeks than in those subjected to intestinal deviation for six weeks. Even though previous studies showed that there were reductions in the thickness of the colon wall and, particularly, the height of the colonic crypts with increasing duration of exclusion, there were increases in the expression of neutral mucins in the colon without transit $\mathrm{i}^{23,24,25}$. It is possible that such increases may be related to maintenance of the proportion of goblet cells (mucin producers), in relation to the other cells that make up the colon epithelium ${ }^{5}$. Corroborating these findings, Biondo-Simões et al. ${ }^{26}$ evaluated a population of goblet cells in rats, comparing colon segments subjected to intestinal deviation for one, two, four and eight weeks, and did not find any significant differences in the number of goblets cells, by means of the PAS technique. These authors did not mention whether any care was taken to remove the fecal content in the excluded colon before performing the intestinal deviation ${ }^{26}$. Keli et al. ${ }^{5}$ evaluated in rats the number of goblet cells in colon mucosa did not find any significant differences in the number of goblets cells after diversion of the fecal stream by 17 weeks. These authors argue that if there is a reduction in the thickness of the colonic crypts and the population of goblet cells remains it is logical to think that exist an increase in absolute number of these cells. In the present study, even with the removal of the fecal content that could have still served as energy substrate for epithelial trophism of the colon mucosa, there was increased tissue production of neutral mucins, thus suggesting that a goblet cell population with the capacity to produce neutral mucins was maintained. This was also found in models of colitis induced by dextran sodium sulfate, thus showing that, despite the reduction in the numbers of goblets cells, there was increased tissue expression of mucins: a phenomenon similar to what is seen in cases of $\mathrm{UC}^{27}$.

Acid mucins present different patterns of histochemical expression according to the colon region in question, and also in relation to their location within the colon glands. While sulfomucins occupy the lower two-thirds of the left colon, they are mainly expressed in the upper two-thirds of the right colon ${ }^{5}$. In turn, sialomucins occupy the whole colon surface in a complementary manner, predominating in the deeper portions of the colon crypts ${ }^{5}$. With the aim of ensuring that the acid mucin quantification was always done in the same region of the colon, the colon specimens for histochemical evaluation, both with and without transit, were removed from predetermined locations in all the animals. Through this, quantification performed on colon segments with naturally different expression patterns, which could have interfered in the results, was avoided.
The proportions between neutral and acid mucins and between sulfomucins and sialomucins are generally constant over the whole surface of the colon and may present changes in several diseases ${ }^{17}$. It has already been demonstrated, both histochemically and biochemically, that the acid mucin content in the colon epithelium becomes modified in patients with UC, and inversion of these proportions is generally considered to the a pathological finding ${ }^{28,29}$. The differences in mucin expression pattern in inflamed colons in humans are also found in $\operatorname{rats}^{30}$. Experimental studies evaluating the histochemical expression of acid mucins in the colon of rats with fecal transit have demonstrated that sulfomucins predominate in the upper portions of the colon crypts, while sialomucins predominate in the deeper regions ${ }^{5}$. Differing from this, in the colon segments without fecal stream, while sialomucins tended to disappear with increasing duration of intestinal exclusion, sulfomucins became more intensely expressed, occupying the whole extent of the colon. Keli et al. ${ }^{5}$ studied the distribution of sulfomucins and sialomucins in the crypts of the colon mucosa in rats that were subjected to intestinal transit for six and 17 weeks and confirmed these findings through observing that sulfomucins presented expression over the whole extent of the colonic crypts and that the intensity of expression increased with increasing duration of exclusion. In studying the expression of sialomucins, they found that the segments with transit presented expression in the lower two-thirds of the colonic crypts, while in the segments without transit, they were expressed only in the lowest third of the crypts after six weeks of exclusion and disappeared completely after 17 weeks of fecal deviation ${ }^{5}$. Thus, according to those authors, the increased expression of acid mucins in the excluded colon was primarily due to greater presence of sulfomucins. However, it should be noted that they did not use any objective measurement method, and the quantification was based on the pathologist's subjective interpretation and thus was subject to evaluation errors. Likewise, they did not describe the methodological care taken for complete elimination of the fecal content from segments excluded from the transit. They suggested that the inversion in the expression of acid mucins that was found particularly after six weeks of exclusion was due to changes in cell turnover, along with greater presence of immature cells, which predominantly produce sulfomucins ${ }^{5}$.

Biondo-Simões et al. ${ }^{26}$ evaluated a population of goblet cells in rats comparing colon segments subjected to intestinal deviation for one and eight weeks, with $\mathrm{AB}$ technique (for acid mucin), found significant differences in the number of goblets cells. The authors found less number of goblet cells producers of acid mucins in the animals subjected the exclusion of the fecal stream for eight weeks. In the present study, a significant reduction in the quantity of acid mucins in the segments without fecal stream could be demonstrated, in relation to the segments with transit, independent of the duration of exclusion considered. The reductions were $47 \%, 65 \%$ and $29 \%$, in the animals subjected to deviation for 6,12 and 18 weeks, respectively. In the segments with fecal transit, there was a $17 \%$ increase in the quantity of acid mucins between the exclusions of 6 and 12 weeks, with a subsequent reduction of $7 \%$ between the exclusions of 12 and 18 weeks. Differently of other authors in the colon segments without fecal transit, there was an increased quantity of acid mucins with increasing of intestinal exclusion ${ }^{26}$. Comparing the acid mucin content in the segments without fecal transit for 18 weeks with those subjected to exclusion for 6 and 12 weeks, increases in 
tissue quantities of $32 \%$ and $47 \%$ respectively were found. It was seen that this increase only presented significant variation when comparing the animals subjected to deviation for 18 weeks with those subjected to exclusion for 6 and 12 weeks. In the same way that was observed in relation to neutral mucins, it is possible that the same arguments are related to this reduction. These findings reinforce the results from previous studies, thus demonstrating that there is increased expression of acid mucins in segments excluded from transit, particularly of sulfomucins ${ }^{5}$.

Studies have been demonstrating changes to the pattern of tissue expression of mucins in chronically inflamed epithelium, as occurs in cases of UC, with increased tissue expression of acid mucins, particularly sialomucins ${ }^{7,31}$. In a different manner in DC cases, a single study demonstrated that there was greater expression of acid mucins of sulfomucin type, with disappearance of sialomucins ${ }^{5}$. Nevertheless, it should again be borne in mind that the authors of that study did not perform mechanical cleaning of the segment excluded from the transit. This would have allowed continuing presence of feces and bacteria that could have maintained the nutrition of the colon and explained the predominance of sulfomucins. In the present study, despite not having differentiated between the subtypes of acid mucins by means of the technique of high iron diamine/Alcian blue (HID-AB), which enables identification of the two mucin subtypes, increased total expression of acid mucins in the segments without transit was demonstrated and that this greater quantity was correlated with increasing duration of exclusion. It is possible that, through using the histochemical technique of HID-AB, together with quantification by computerized morphometry and an adequate experimental model for transit exclusion, it will be possible to confirm whether the increased quantity of acid mucins in the excluded colons with increasing duration of exclusion is more related to a given subtype of acid mucin. We are now using computerized morphometry in the same animals, with the HID-AB technique, to measure the expression of subtypes of acid mucins, comparing segments with and without transit, to investigate the relationship of each subtype with the duration of exclusion. Thus, we will be able to confirm, with an appropriate experimental model, whether increases in sialomucins and sulfomucins exist in cases of DC, in the same way that they do in cases of UC.

The interest in the quantification of the expression pattern of mucins in segments without intestinal stream is important, considering that previous studies showed that chronically inflamed colon epithelium, with varying degrees of tissue dysplasia or cancer, predominantly shows expression of acid mucins, mainly of sialomucin type $^{32}$. Likewise, experimental studies evaluating the relationship between mucins, metaplasia or cancer, in animals subjected to urinary deviation using colon segments, have demonstrated modifications in the expression pattern of mucins, with predominance of acid mucins, particularly sialomucins. This changes occurs specifically in the transition epithelium around the anastomosis, which is exactly the location most subject to the appearance of neoplasia ${ }^{9}$. Schauffert et al. ${ }^{11}$ studied by histomorphometry the alterations in the ileal mucosa of rats that were submitted to ileocystoplasty for four and 12 weeks, found atrophy and transitional metaplasia that were associated to increase of goblet cells (producers of sialomucins), more pronounced in the group of 12 weeks. Nevertheless, others authors evaluating the tissue expression of mucins in rats submitted to anastomosis between urinary tract (bladder) and left colon found a significant reduction in the amount of acid and neutral mucins at the anastomotic site 9 These authors found a decrease in the amount of sulfomucin and an increase in the sialomucin content in the left colon, though this change in secretion of sulfomucin and sialomucin was significant only at the anastomotic site ${ }^{9}$.

Since there is parallelism between the histological characteristics of DC and UC, it is possible that colon segments chronically inflamed, without fecal stream, may also be subject to the appearance of tissue dysplasia and even neoplasia, which may also be preceded by changes to mucin expression in the colon epithelium. Furthermore, evaluation of the mucin expression in epithelium without fecal stream may enable comparisons of the therapeutic efficacy of different substances that are used for treating DC, such as SCFA, probiotics, antioxidants and anti-inflammatory drugs, investigating the effect of these substances on mucus production by the colon epithelium and their efficacy for preventing the development of dysplasia and colorectal cancer.

\section{Conclusions}

There is a significant reduction in the expression of neutral and acid mucins in colon segments without fecal transit, in comparison with segments with transit, independent of the duration of exclusion. It is also concluded that, despite the reduction in the expression of neutral and acid mucins in the segments of the colon without fecal stream, there is an increase in tissue expression in the excluded colon, with increasing duration of intestinal exclusion.

\section{References}

1. Glotzer DJ, Glick ME, Goldman H. Proctitis following diversion of fecal stream. Gastroenterol. 1981;80(3):438-41.

2. Giardiello FM, Lazenby AJ, Bayless TM. The new colitides: collagenous, lymphocytic, and diversion colitis. Gastroenterol Clin North Am. 1995;24(3):717-29.

3. Korelitz BI, Cheskin LJ, Sommers SC. The fate of the rectal segment after diversion of the fecal stream in Crohn's disease: its implication for surgical management. J Clin Gastroenterol. 1985;7(1):37-43.

4. Kiely EM, Ajayi NA, Wheele RA, Malone M. Diversion procto-colitis: response to treatment with short-chain fatty acids. J Pediatr Surg. 2001;36(10):1514-7.

5. Keli E, Bouchoucha M, Devroede G, Carnot F, Ohrant T, Cugnenc PH. Diversion-related experimental colitis in rats. Dis Colon Rectum. 1997;40(2):222-8

6. Habib NA, Dawson PM, Krausz T, Blount MA, Kersten D, Wood CB. A study of histochemical changes in mucus from patients with ulcerative colitis, Crohn's disease, and diverticular disease of the colon. Dis Colon Rectum. 1986;29(1):15-7.

7. Agawa S, Muto T, Morioka Y. Mucin abnormality of colonic mucosa in ulcerative colitis associated with carcinoma and/or dysplasia. Dis Colon Rectum. 1988;31(5):387-9.

8. Allen DC, Connolly NS, Biggart JD. Mucin profiles in ulcerative colitis with dysplasia and carcinoma. Histopathology. 1988;13(4):413-24. 9. Castro MA, Ferreira U, Martins MH, Stoppiglia RM, Netto Júnior NR. Histological and histochemical changes of the intestinal mucosa at the urothelial-enteric anastomotic site. Int Braz J Urol. 2006;32(2):222-7. 10. Shimamoto C, Hirata I, Takao Y, Takiuchi H, Morikawa H, Nakagawa Y, Katsu K. Alteration of colonic mucin after ureterosigmoidostomy. Dis Colon Rectum. 2000;43(4):526-31. 
11. Schauffert MD, Biondo-Simões MLP, Juliano Y, Simões MJ, Novo NF, Ortiz V. Estudo histológico e histométrico das vilosidades e das células caliciformes ileais na ileocistoplastia em ratas. Acta Cir. Bras. [periódico na Internet]. 1999 Jul-Set;14(3). Disponível em URL: http://www.scielo.br/acb. 12. Martinez CAR, Waisberg J, Palma RT, Silva FZ, Cimerman G, Goffi FS. Morphometric study of gastric mucosa in dogs submitted to proximal gastric vagotomy, splenectomy or proximal gastric vagotomy associated with splenectomy. Acta Cir Bras. 2002;17(5):289-98.

13. Priolli DG, Margarido NF, Martinez CAR, Rotta CM, Stephani SM. Edema quantification by computerized morphometry as an evaluation parameter for the resistance of colon anastomoses. Acta Cir Bras. 2003;18(5):398-406.

14. Gilks CB, Reid PE, Clement PB, Owen DA. Simple procedure for assessing relative quantities of neutral and acidic sugars in mucin glycoproteins: its use in assessing cyclical changes in cervical mucins. J Clin Pathol. 1988;41(9):1021-4.

15. Finnie IA, Dwarakanath AS, Taylor BA, Rhodes JM. Colonic mucins synthesis is increased by sodium butyrate. Gut. 1995;36(1):93-9.

16. Rhodes JM, Black RR, Savage A. Altered lecitin binding by colonic epithelial glycoconjugates in ulcerative colitis and Crohn's disease. Dig Dis Sci. 1988;33(11):1359-63.

17. Clamp JR, Fraser G, Read AE. Study of the carbohydrate content of mucus glycoproteins from normal and diseased colons. Clin Sci. 1981;61(2):229-34.

18. Brownlee IA, Knight J, Dettmar PW, Pearson JP. Action of reactive oxygen species on colonic mucus secretions. Free Radic Biol Med. 2007;43(5):800-8.

19. Pravda J. Radical induction theory of ulcerative colitis. World J Gastroenterol. 2005;11(16):2371-84.

20. Martinez CAR, Ribeiro ML, Priolli DG, Alfredo CH, Miranda DDC. Quantificação dos níveis de estresse oxidativo ao DNA de células da mucosa cólica na colite de exclusão. Estudo experimental em ratos. Rev Bras Coloproctol. 2008;28(Supl. 1):47.

21. Stein DT, Paldi JH, Goodnin DA. In-111 leucocytes scan in "diversion"colitis. Clin Nucl Med. 1983;8(1):1-2.

22. Sharma R, Schumacher U. Morphometric analysis of intestinal mucins under different dietary conditions and gut flora in rats. Dig Dis Sci. 1995;40(12):2532-9.
23. Kissmeyer-Nielsen P, Christensen H, Laurberg S. Diverting colostomy induces mucosal and muscular atrophy in rat distal colon. Gut. 1994;35(9):1275-81.

24. Nasrri CGG, Nasrri AB, Favero E, Rotta CM, Martinez CAR, Margarido NF. Influência da irrigação de soluções nutricionais no colo excluso de trânsito intestinal. Estudo experimental em ratos. Rev Bras Coloproctol. 2008;28(3):306-14.

25. Sousa MV, Priolli DG, Portes AV, Cardinalli IA, Pereira JA, Martinez CAR. Evaluation by computerized morphometry of histopathological alterations of the colon wall in segments with and without intestinal transit in rats. Acta Cir. Bras. 2008;23(5):417-24.

26. Biondo-Simões MLP, Greca FH, Ioshi S, Abicalaffe MD, Colnaghi MC, Mattos e Silva E, Yamasaki ES, Smaniotto G. Colite do cólon excluso: modelo experimental em ratos. Acta Cir Bras. 2000;15(Supl.3):7-11.

27. Nakano S, Ohara S, Kubota T, Saigenji K, Hotta K. A study of colonic mucins in two kinds of experimental colitis model in rat. Nippon Shokakibyo Gakkai Zasshi. 1998;95(6):513-23.

28. Reid PE, Culling CFA, Dunn WL, Ramey CW, Clay MG. Chemical and histochemical studies of normal and diseased human gastrointestinal tract. I. A comparison between histologically normal colon, colonic tumours, ulcerative colitis and diverticular disease of the colon. Histochem J. 1984;16(3):235-51.

29. Laboisse C, Bogomoletz WV. Lês mucines: dês glycoprotéines em quête de reconneissance. Ann Pathol. 1989;9(3):175-81.

30. Freeman HJ, Lotan R, Kim SY. Application of lectins for detection of globet cell glycoconjugate differences in proximal and distal colon of the rat. Lab Invest. 1980;42(4):405-9.

31. Jass JR, Sugihara K, Love SB. Basis of sialic acid heterogeneity in ulcerative colitis. J Clin Pathol. 1988;41(4):388-92.

32. Filipi MI. Value of histochemical reactions for mucosubstances in the diagnosis of certain pathological conditions of the colon and rectum. Gut. 1969;10(7):57-86.

\section{Acknowledgment}

The authors are grateful to Mr. David Elliff, for assistance in version to English language.

\section{Correspondence:}

Carlos Augusto Real Martinez

Rua Rui Barbosa, 255/32

09190-370 Santo André - SP Brazil

Phone: (55 11)4438-9203

caomartinez@uol.com.br

Conflict of interest: none Financial source: FAPESP

Process 2006-02306-6

(1)

$+2$

Received: January 19, 2009

Review: March 20, 2009

Accepted: April 15, 2009

\section{How to cite this article}

Nonose R, Spadari APP, Priolli DG, Máximo FR, Pereira JA, Martinez CAR. Tissue quantification of neutral and acid mucins in the mucosa of the colon with and without fecal stream in rats. Acta Cir Bras. [serial on the Internet] 2009 July-Aug;24(4). Available from URL: http://www.scielo.br/acb 